\title{
Influence of Osmodehydration Pretreatment and Combined Drying Method on the Bioactive Potential of Sour Cherry Fruits
}

\author{
Paulina Nowicka • Aneta Wojdyło • Krzysztof Lech • \\ Adam Figiel
}

Received: 13 June 2014 / Accepted: 24 November 2014 / Published online: 6 December 2014

(C) The Author(s) 2014. This article is published with open access at Springerlink.com

\begin{abstract}
The aim of this study was to determine the effect of osmotic dehydration (OD) time in apple concentrate on dehydration kinetics and quality parameters (polyphenol content and antioxidant activity) of sour cherries before further processing. Additionally, the study was focused on the effects of combined drying (convective drying + vacuum-microwave finish drying (CD-VMFD)) applied to fresh and osmodehydrated sour cherries in respect to drying kinetics, including the temperature evolution of dried material with time, as well as on quality factors of the finished product. Analyses were conducted for four kinds of sour cherries: frozen with stone (FS), frozen without stone (FW), thawed with stone (TS), and thawed without stone (TW), which were osmodehydrated for $180 \mathrm{~min}$ in the same operating conditions. The study revealed that the decrease of water loss to solid gain (WL/SG) ratio during OD of frozen sour cherries in apple concentrate associated with increased values of WL/SG was considerably enhanced by stone removal and the process of thawing. A logarithmic model was proposed for overall description of drying kinetics of combined drying. While OD time was increasing, the drying constant was decreasing for $\mathrm{CD}$ and obtained the maximum value for VMFD at the optimal time of OD, which was associated with achieving the peak temperature of VMFD material. It was found that the best variant of pretreatment of sour cherries, to be used for OD in apple concentrate, was freezing the fruits without stones. These fruits were characterized by a high content of
\end{abstract}

P. Nowicka $\cdot$ A. Wojdyło $(\square)$

Department of Fruit and Vegetable Technology, Wrocław University

of Environmental and Life Science, 37/41 Chełmońskiego Street,

51-630 Wroclaw, Poland

e-mail: anetajb@op.pl

K. Lech · A. Figiel

Institute of Agricultural Engineering, Wrocław University of

Environmental and Life Science, 37/41 Chełmońskiego Street,

51-630 Wrocław, Poland polyphenols, high antioxidant activity, and the largest WL/SG ratio during OD process. It was also stated that the optimal method for sour cherry drying was the combined method consisting of OD (120 min) followed by CD $(90 \mathrm{~min})$ and VMFD, while maintaining the initial parameters.

Keywords Osmotic dehydration · Drying · Polyphenols · Antioxidant activity

\section{Nomenclature}

$A B \quad$ function parameter

ABTS 2,2'-Azino-bis(3-ethylbenzothiazoline-6sulphonic acid)

ANOVA Analysis of variance

CD Convective drying

$d b \quad$ Dry weight

FS Frozen sour cherries with stones

FW Frozen sour cherries without stones

$k \quad$ Drying constant $\left(\mathrm{min}^{-1}\right)$

$M \quad$ Current moisture content $\left(\mathrm{kg} \mathrm{kg}^{-1} \mathrm{db}\right)$

$M_{e} \quad$ Equilibrium moisture content $\left(\mathrm{kg} \mathrm{kg}^{-1} \mathrm{db}\right)$

$M_{0} \quad$ Initial moisture content $\left(\mathrm{kg} \mathrm{kg}^{-1} \mathrm{db}\right)$

$M_{O D} \quad$ Moisture content after osmotic dehydration $\left(\mathrm{kg} \mathrm{kg}^{-1} \mathrm{db}\right)$

$M_{f} \quad$ Final moisture content $\left(\mathrm{kg} \mathrm{kg}^{-1} \mathrm{db}\right)$

MR Moisture ratio

OD Osmotic dehydration

$\mathrm{R}^{2} \quad$ Coefficient of determination

RMSE Root mean square error

$s \quad$ Current value for mass of solids in the sample

$s_{0} \quad$ Initial value for mass of solids in the sample

$S G \quad$ Solid gain

$t \quad$ Temperature $\left({ }^{\circ} \mathrm{C}\right)$

$\tau \quad$ Time (min)

Trolox (6-Hydroxy-2,5,7,8-tetramethylchroman-2-carboxylic acid) 


$\begin{array}{ll}\text { TS } & \text { Thawed sour cherries with stones } \\ \text { TW } & \text { Thawed sour cherries without stones } \\ \text { VMFD } & \text { Vacuum-microwave finish drying } \\ w & \text { Current value for sample weight } \\ w_{0} & \text { Initial value for sample weight } \\ W L & \text { Water loss } \\ W R & \text { Weight reduction }\end{array}$

\section{Introduction}

Sour cherry (Prunus cerasus L.) is one of the most attractive fruits in terms of nutritional value and sensory properties. It is characterized by intense red color and sour-sweet taste and contains many bioactive components beneficial for health, such as polyphenols or organic acids (Tarhan et al. 2006). Anthocyanins present in sour cherry fruit, which impart the red color to the raw material, exhibit antioxidant, anti-inflammatory, antibacterial, and antidiabetic activities (Halvorsen et al. 2002). Organic acids that affect its sour taste additionally stimulate the secretion of digestive enzymes, vitamins, and minerals and are responsible for the proper course of chemical reactions in the body (Seymour et al. 2008). However, sour cherry is a seasonal fruit, and most processing technologies cause significant degradation of its bioactive compounds. Therefore, new less invasive solutions are searched for that would ensure a similar nutritional value of processed cherry to that of the raw material.

Apart from the above, some limitation in the processing of sour cherries is also the short harvest season (about 1 month) and harvest size which, depending on the season, ranges from 150 to over 200 thousand tons per year, of which $70 \%$ is intended for further processing (Nowicka et al. 2013). It means that on average, 130 thousand tons of sour cherries need to be processed in a very short period of time, which is not always possible from the technological point of view. In order to minimize losses of raw materials, an appropriate method of pretreatment should be found that will allow preserving the nutritional value of the material, without causing too much increase in process costs. A good idea in this case might be the prefreezing of stoned sour cherries or cherries with stone, which is one of the most common and the least invasive methods of food preservation (Gomez and Sjoholm 2004). In addition, freezing could be an excellent pretreatment for osmotic dehydration of fruit and vegetable, improving significantly mass transfer during osmotic process. Bchir et al. (2012a) showed that freezing pomegranate seeds before osmotic dehydration provided 1.4 and 3.5 times more water loss and solid gain, respectively, than those in the untreated seeds. In the next step, an attempt may be undertaken to dry sour cherries without causing losses of fresh material due to storage of cherries in the fresh form. The question is, however, what kind of drying methods to choose to ensure the top quality finished product.

Drying is a method which has several advantages related to economies of storage and distribution of the final product, but it also involves significant degradation of bioactive compounds (Aghbashlo et al. 2010). Thus, new solutions are currently searched for that are associated with pretreatment of the raw material and supporting processes which retain the quality of sour cherries while allowing the production cost to be kept at the same level. One of such methods is the coupled use of osmotic dehydration (OD), convective drying (CD), and vacuum-microwave finish drying (VMFD). OD is used to reduce water and to increase sugar content in fruit and vegetables. It consists in immersing the raw material in a hypertonic solution. The difference of the chemical potential between the material and the solution stimulates mass transfer processes between the plant tissue and the surrounding solution. As a result, the osmotically dehydrated material is characterized by a low-water activity, which ensures higher stability during storage (Abraao et al. 2013). Usually, a sucrose solution is applied as the hypertonic solution; however, an interesting alternative seems to be the use of other media, for example, concentrated fruit juice. Bchir et al. (2012c) showed many advantages of using fruit juice to this end, namely, the increase of economic gain by reducing the amount of sucrose added to the osmotic solution and a high nutritional value of the final product. CD using hot air is still the most common method to produce dried products because of its low costs. Many authors propose the use of CD following OD for fruits and vegetables, as a good method to produce a uniformly dried product (Bchir et al. 2012c; El-Aouar et al. 2003; Mandala et al. 2005; Sereno et al. 2001). However, this method requires relatively long time and high temperatures to obtain safe moisture content of the dried product. This causes degradation of nutrients and color alteration (Figiel 2010; Wojdyło et al. 2014). Despite this, CD in hot air is still worth considering due to the satisfactory efficiency at the initial period of dehydration characterized by a relatively high drying rate and large capacity. Therefore, $\mathrm{CD}$ should be followed by a method which can ensure the appropriate drying rate at the final period of dehydration and high quality of the dried products (Mayor and Sereno 2004). One of these methods applied after CD could be VMFD. Drying with the microwave method under vacuum is an advanced and fast way to maintain the high quality of the dried product. As a result, these combined systems of air and microwave drying not only increase drying rates but also better preserve the quality of the dry products (Figiel 2010). The quality of the final product can be also improved by applying osmotic pretreatment prior to $\mathrm{CD}$ (OD$\mathrm{CD}$ ). This combination of drying was successfully applied for pomegranates (Bchir et al. 2012c). No scientific work has yet been reported on the combined drying (OD-CD-VMD) of sour cherries osmotically pretreated before processing. The 
combination of these methods could make a significant contribution to the sour cherry processing industry. However, it is not obvious how long the OD process should last and when CD should be replaced with VM method. On the other hand, the concentrate of apple can be treated as a relatively cheap natural substitute of a sucrose solution, which is commonly applied for OD (Abraao et al. 2013; Azoubel and Murr 2003; Falade and Adelakun 2007; Kowalska et al. 2008; Mandala et al. 2005; Sereno et al. 2001) despite the negative perception of sugar in food products by many consumers (Williams 2005). Moreover, the manufacturing of apple concentrate is an excellent option for fruit utilization in crisis situations resulting from the overproduction of apples or fruit market turmoil. Therefore, the aim of this study was to determine the effect of OD in apple concentrate on physicochemical and quality parameters (polyphenol content and antioxidant activity) of sour cherries subjected to further processing. The effects of combined drying (OD-CD-VMD) on sour cherries in respect to drying kinetics, including the temperature evolution of dried material with time, as well as on some quality factors of the finished product including phenolic compounds and antioxidant activity, were also evaluated.

\section{Materials and Methods}

\section{Chemicals}

Trolox (6-hydroxy-2,5,7,8-tetramethylchroman-2-carboxylic acid), 2,2'-azinobis-(3-ethylbenzthiazoline-6-sulfonic acid) (ABTS), sodium dihydrophosphate, Folin-Ciocalteu's phenol reagent, gallic acid, sodium carbonate anhydrous pure p.a., and methanol were purchased in Sigma-Aldrich (Poznań, Poland).

\section{Materials}

Samples of sour cherry cultivar "Turgieniewka" were collected in June 2012 from the Experimental Station for Cultivar in Zybiszów near Wroclaw. Sour cherries were frozen at $-20{ }^{\circ} \mathrm{C}$ (Byfal s.c zd 700; Poznan, Polska) immediately after harvested in order to facilitate the process of mass transfer during OD (Falade and Adelakun 2007; Kowalska et al. 2008). The initial moisture content of frozen sour cherries with stones (FS), frozen sour cherries without stones (FW), thawed sour cherries with stones (TS), and thawed sour cherries without stones (TW) were 4.90, 7.30, 4.59, and $6.45 \mathrm{~kg} \mathrm{~kg}^{-1} \mathrm{db}$, respectively. Concentrate of apple was from RAUCH Polska Sp.z o.o. (Lęczyca, Poland).

\section{Osmotic Dehydration Experiments}

Just before OD process, four different variants of sour cherries (average fruit weight with stone $6 \mathrm{~g}$; average fruit weight without stone $5.2 \mathrm{~g}$; each sample weight $60 \mathrm{~g}$ ) were prepared: (i) FS, (ii) FW, (iii) TS, and (iv) TW. Then, apple concentrate was diluted until $40^{\circ}$ Brix and heated up to $40{ }^{\circ} \mathrm{C}$, and afterward, the different types of material $(60 \mathrm{~g})$ were distributed into separate beakers containing the osmotic solution $(120 \mathrm{~mL})$. Beakers were immersed in a water bath that maintained the desired temperature. OD process was carried out for $180 \mathrm{~min}$. These conditions concerning concentration and temperature of osmotic solution have been found as the best on the basis of the results obtained in the previous studies made on pumpkin (Figiel et al. 2011). These results also showed that processing time was long enough to determine the optimal duration of osmotic pretreatment. The volume ratio between the fruit and the apple solution was kept at one part of fruit and two parts of solution (1:2). Samples were taken every $30 \mathrm{~min}$ from the beakers with solution in order to determine the kinetics of OD, total phenolic content, and antioxidant activity. The dry matter content of sour cherry samples was determined by drying the previously taken samples in a vacuum dryer (SPT-200; ZEAMiL Horyzont, Krakow, Poland) for $24 \mathrm{~h}$ at a temperature of $60{ }^{\circ} \mathrm{C}$ (Wojdyło et al. 2014). Two technological repetitions were performed for each treatment.

\section{Convective Drying}

The process of $\mathrm{CD}$ was performed in a drier designed and built in the Institute of Agriculture Engineering (Wroclaw, Poland). The air temperature and velocity were $50{ }^{\circ} \mathrm{C}$ and $0.8 \mathrm{~m} / \mathrm{s}$, respectively. The untreated samples and samples pretreated by OD were spread on a round 100-mm tray. The tray was placed on top of a drying pipe. The convective dryer, equipped with six pipes, enabled simultaneous drying of six portions. CD was carried out for $90 \mathrm{~min}$ despite of the initial moisture content of untreated or pretreated samples. Therefore, the final moisture content of CD samples was different and relatively high with respect to dried fruits available in the market. In order to obtain crispy texture, additional drying was necessary. The results of many studies proved that VMFD is the best method for this purpose (Maskan 2000; Durance and Wang 2002; Bohm et al. 2006; Figiel 2010).

\section{Vacuum-Microwave Finish Drying}

The process of VMFD of predried samples took place in SM200 dryer (Plazmatronika, Wroclaw, Poland) at 360-W microwave power. The pressure in the vacuum drum ranged from 4 to $6 \mathrm{kPa}$, and the drum was revolving at $6 \mathrm{rev} / \mathrm{min}$ in order to avoid the local overheating of sour cherry samples. Nevertheless, the temperature of individual fruits differed despite of the drum rotation. The temperature of sour cherry fruits was measured with an infrared camera Flir i50 (Flir Systems AB, Sweden) immediately after taking them out of the VM dryer. The external temperature of most heated fruits was recorded. It 
was supposed that the temperature measured with this method reflected the course of mean temperature during VMFD. The process of drying was terminated when the moisture content of samples reached value ca. $0.05 \mathrm{~kg} \mathrm{~kg}^{-1} \mathrm{db}$.

\section{Drying Kinetics}

Determination of drying kinetics of OD of sour cherries required calculating the following: weight reduction $(W R)$, solid gain $(S G)$, and water loss $(W L)$ expressed in $\mathrm{g} / 100 \mathrm{~g}$ of fresh fruits using following equations (Bchir et al. 2012c):

$W R=\frac{w_{i}-w}{w_{i}} \times 100$

$S G=\frac{s^{-} s_{i}}{w_{i}} \times 100$

$$
W L=S G+W R
$$

where $w, w_{i}$ and $s, s_{i}$ are the current and initial values for weight of sample $(\mathrm{g})$ and solid content in the sample $(\mathrm{g})$, respectively.

Calculation of solid gain $(S G)$ and water loss $(W L)$ enabled determining the $W L / S G$ ratio, which is often applied to characterize the process of mass exchange during OD (Sereno et al. 2001; Azoubel and Murr 2003). Because the mass of solids was changing during OD, it was necessary to determine the value of this parameter by the oven method whenever the successive samples were taken out from the osmotic solution.

The drying kinetics of convective and VM methods of drying was determined on the basis of mass losses of sour cherry samples. The weighing time interval was $3 \mathrm{~min}$ for VMD and $5 \mathrm{~min}$ at the very beginning of $\mathrm{CD}$ and was prolonged up to 10 and $15 \mathrm{~min}$ after 20 and $60 \mathrm{~min}$ of drying, respectively. Usually, in these cases of drying processes, the moisture ratio $M R$ is calculated from the equation:

$M R=\frac{M-M_{e}}{M_{0}-M_{e}}$

where

\section{$M \quad$ current moisture content \\ $M_{0} \quad$ initial moisture content}

Equilibrium moisture content $M_{e}$ can be reached after enough long time of drying at constant conditions for particular method of drying. In this study, $M_{e}$ was considered in relation to VM method which provides dried samples with a very low final moisture content. The values of $M_{e}$ were a bit lower than the final moisture content of maximally dried samples. Such low values of $M_{e}$ had negligible effect on $M R$, which depended mainly on values of $M$ and $M_{0}$.
Therefore, accordingly to some authors (Alibas 2006), $M R$ was determined as the ratio of $M$ to $M_{0}$.

Modeling of Drying Kinetics

A logarithmic model (Eq. 5) was fitted to the experimental points representing a decrease of $M R$ with time of $C D$ and VMD using Table Curve 2D Windows v2.03 (Jandel Scientific Software, USA). This drying model is commonly used due to its relatively simple form and high applicability (Wojdyło et al. 2009; Lech et al. 2012; Calín-Sanchez et al. 2014).

$M R=A \cdot e^{-k \cdot}+B$

A drying constant $k$ delvers information on drying rate, while the two parameters $A$ and $B$ enable fitting to the experimental points for $\mathrm{CD}$ and VMD drying as well as combination of these methods. OD was considered as a pretreatment process changing condition of the material subjected to successive drying in terms not only of proportion of water to dry matter, but also physical properties and chemical composition. Therefore, $M R$ for osmotically pretreated samples was calculated by dividing current moisture content $(M)$ by moisture content obtained after OD $\left(M_{O D}\right)$, which was much lower than initial moisture content $\left(M_{0}\right)$ determined for the fresh sample.

\section{Total Polyphenol Content}

The solvent for analysis was prepared as described previously by Wojdyło et al. (2009). The total phenolic content was determined according to the modified Folin-Ciocialteu method described by Gao et al. (2000) which was performed in triplicate using a Shimadzu UV-2401 PC spectrophotometer (Kyoto, Japan). The results of total polyphenol content were expressed relative to milligrams of gallic acid per 100-g dry matter (mg GA/100 g dm).

\section{Analysis of Antioxidant Activity}

The solvent for analysis was prepared as described previously by Wojdyło et al. (2009). The ABTS ${ }^{++}$activity of a sample was determined according to the method of Re et al. (1999) which was performed in triplicate using a Shimadzu UV-2401 PC spectrophotometer (Kyoto, Japan). The results of antioxidant activity were expressed relative to millimoles of Trolox per $100 \mathrm{~g}$ of dry matter (mmol TE/100 g dm).

Statistical Analysis

Statistical analysis was conducted using Statistica version 9.0 (StatSoft, Krakow, Poland). Significant differences $(p \leq 0.05)$ 
between means were evaluated by one-way ANOVA and Duncan's multiple range test. Results of tables and figures are presented as mean \pm standard deviation. All analyses were done in triplicate.

\section{Results and Discussion}

\section{Osmotic Dehydration}

The kinetics of OD depicting an increase of water loss $(W L)$ and solid gain $(S G)$ for different types of sour cherries dehydrated for $180 \mathrm{~min}$ in the osmotic solution prepared from the concentrated apple juice is shown in Figs. 1 and 2, respectively.

In this study, OD of sour cherries without stone (frozen and also thawed) caused higher increase of $W L$ than that in fruit with stone. This was specially visible in the very beginning of the process when the increase of $W L$ was highly intense. This process was enhanced by the pitting of sour cherries, which caused damage to the natural barrier which is the skin of the fruit. In this way, additional channels were created, enabling faster removal of moisture by increasing the diffusivity of water. Hence, the OD process was more efficient in terms of $W L$ increase. The course of $W L$ curves indicates that OD of fruits without stones (FW, TW) takes place at higher rates compared with OD of fruits with stones (FS, TS), which was expected assuming that the peal of sour cherries acts as a barrier to mass exchange during OD. It was also found that the process of thawing decreased the intensity of $W L$. This was associated with leakage of water from the material while thawing and thus reduction of its moisture content determined just prior to OD. As a result, the most intensive dehydration was found for frozen fruits without stones (FW). In this case, the highest value of $W L$ achieved already in the thirtieth minutes remained almost constant until the end of OD process. On the other hand, the increase of $S G$ was also enhanced by stone removal from the fruit. However, the absorption of solids from the concentrated apple juice was inhibited for $2 \mathrm{~h}$ in the case of the fruits without stone which were not thawed before OD. During the next hour, these fruits absorbed solids at a much higher rate than before. Eventually, at the very end of OD, the value of $S G$ for fruits without stone was similar regardless of the process of thawing. Noteworthy is that solid gain for fruits with stone was negligible although the water loss was noticeable, which is confirmed by $W L / S G$ ratio (Fig. 3). Namely, the final values of $W L / S G$ ratio for FS and TS fruits amounting to 16.47 and 14.99 , respectively, were significantly higher than values for FW and TW fruits which were 3.22 and 2.23 , respectively. This demonstrates the selective function of sour cherry skin for water and solid migration during OD, even though the freezing pretreatment was performed in order to improve mass transfer (Falade and Adelakun 2007; Kowalska et al. 2008) and enhance solid gain (Lazarides and Mavroudis 1995; Bchir et al. 2012a), which should help achieving values of the $W L / S G$ ratio close to 1 . The process of thawing only slightly decreased $W L / S G$ ratio favoring solid gain, which leads to deterioration of product quality in the case of the osmotic solution prepared from sodium chloride or sucrose (Sereno et al. 2001). However, concentrated apple juice was used in this study, and therefore, high values of $S G$ at low values of $W L / S G$ ratio should not be perceived negatively by consumers, particularly by those who accept fruity taste and avoid excessive intake of salt or sugar.

The intensive mass exchange at the very beginning of OD results from a greater driving force, i.e., the osmotic pressure gradient between the osmotic solution and the cell sap of the plant tissue (Nowacka et al. 2014). Both slowing the loss of water and also increase of dry matter in alternate process steps are the consequence of reducing water diffusion from the surface layers of cells and a slight increase of osmotic flux penetration (Lenart 1992).
Fig. 1 Increase of water loss $(W L)$ for frozen sour cherries with stones $(F S)$ frozen sour cherries without stones $(F W)$, towed sour cherries with stones (TS), and towed sour cherries without stones $(T W)$, versus the time of osmotic dehydration in concentrated apple juice

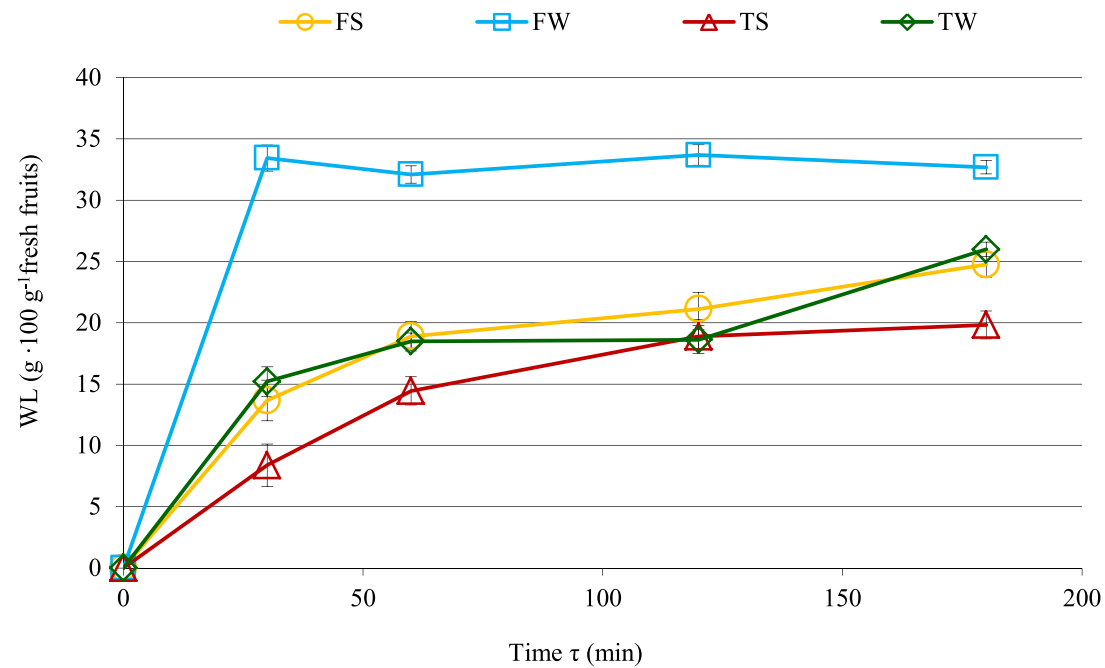


Fig. 2 Increase of solid gain $(S G)$ for frozen sour cherries with stones $(F S)$ frozen sour cherries without stones $(F W)$, towed sour cherries with stones $(T S)$, and towed sour cherries without stones $(T W)$, versus the time of osmotic dehydration in concentrated apple juice

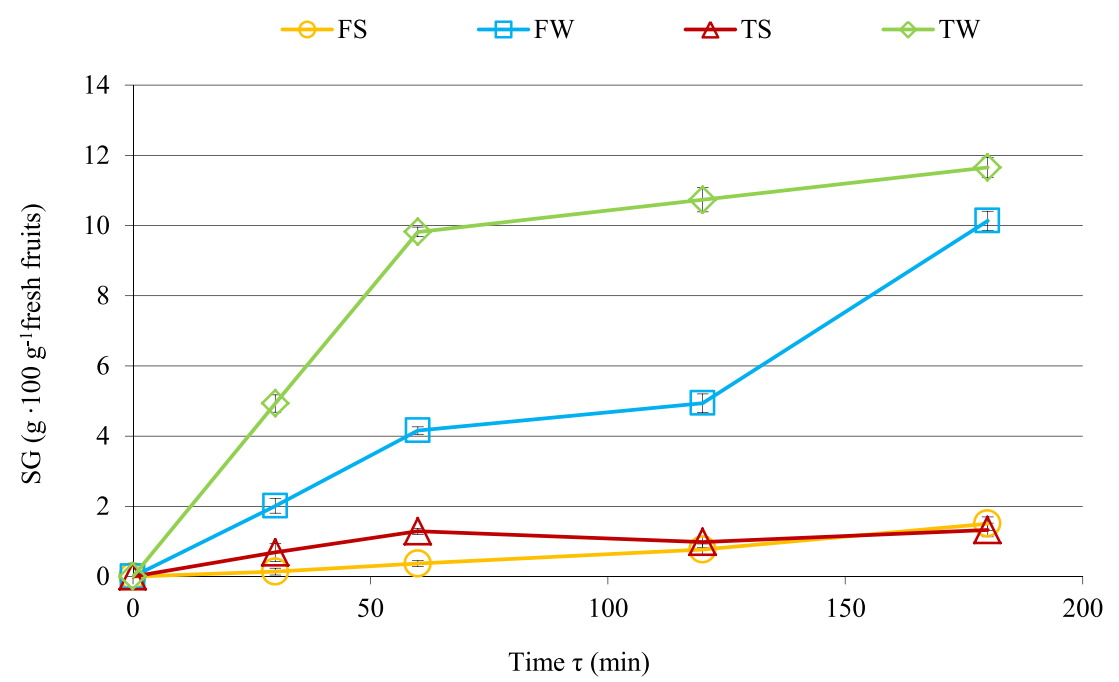

\section{Convective Drying}

The drying kinetics of untreated and osmotically pretreated frozen sour cherries with and without stones, dehydrated with the convective method for $90 \mathrm{~min}$, is shown in Fig. 4. The parameters of Eq. 5 describing the course of $M R$ versus time and values of final moisture content $M_{f}$ are presented in Table 1. The highest value of $M_{f}$ reaching $3.51 \mathrm{~kg} \mathrm{~kg}^{-1} \mathrm{db}$ was obtained for untreated fruits with stones. The osmotic pretreatment of these fruits for $0.5,1$, and $2 \mathrm{~h}$ decreased the value of $M_{f}$ to 2.85 , 2.36 , and $2.31 \mathrm{~kg} \mathrm{~kg}^{-1} \mathrm{db}$, respectively. The noticeable decrease of $M_{f}$ was found only for the samples without stones. In this case, the value of $M_{f}$ ranged from 1.84 to $2.50 \mathrm{~kg} \mathrm{~kg}^{-1} \mathrm{db}$ depending on the time of osmotic pretreatment. However, the increase in time of osmotic pretreatment only slightly decreased $M_{f}$. It is worth noting that the osmotic pretreatment resulted in a decrease of drying constant $k$ values (Table 1) from 0.04 and $0.0657 \mathrm{~min}^{-1}$ to 0.0074 and $0.0106 \mathrm{~min}^{-1}$ for cherries with and without stones, respectively, which is directly associated with a decreasing drying rate (Figiel 2010). This is caused by diminishing of water diffusivity within the dried material due to impregnation of cellular structure leading to clogging the pores of the material by solids from apple concentrate (Lech et al. 2012). Considerably lower values of $k$ for fruits with stones demonstrate that cherry peel is still a large barrier for water penetration, despite of freezing pretreatment.

\section{Vacuum-Microwave Finish Drying}

Figures 5 and 6 depict VM drying kinetics of frozen sour cherries, with and without stones, which were previously predried for 90 min with $\mathrm{CD}$ after osmotic pretreatment for $0,0.5$, and $2 \mathrm{~h}$. All VMFD samples achieved safe values of $M_{f}$ ranging from 0.033 to $0.065 \mathrm{~kg} \mathrm{~kg}^{-1} \mathrm{db}$ (Table 1). The VM drying time of samples with stones was $21 \mathrm{~min}$ in the case of fruits which were untreated or pretreated for $30 \mathrm{~min}$ and $18 \mathrm{~min}$ in the case of fruits pretreated for 1 or $2 \mathrm{~h}$. The shorter time of VMFD detected for the latter two samples resulted from the lower value of moisture content obtained after osmotic pretreatment $M_{O D}$ that reached 3.2 and $2.9 \mathrm{~kg} \mathrm{~kg}^{-1} \mathrm{db}$,
Fig. 3 Final values of $W L / S G$ ratio obtained during osmotic dehydration for frozen sour cherries with stones (FS) frozen sour cherries without stones $(F W)$, towed sour cherries with stones (TS), and towed sour cherries without stones $(T W)$

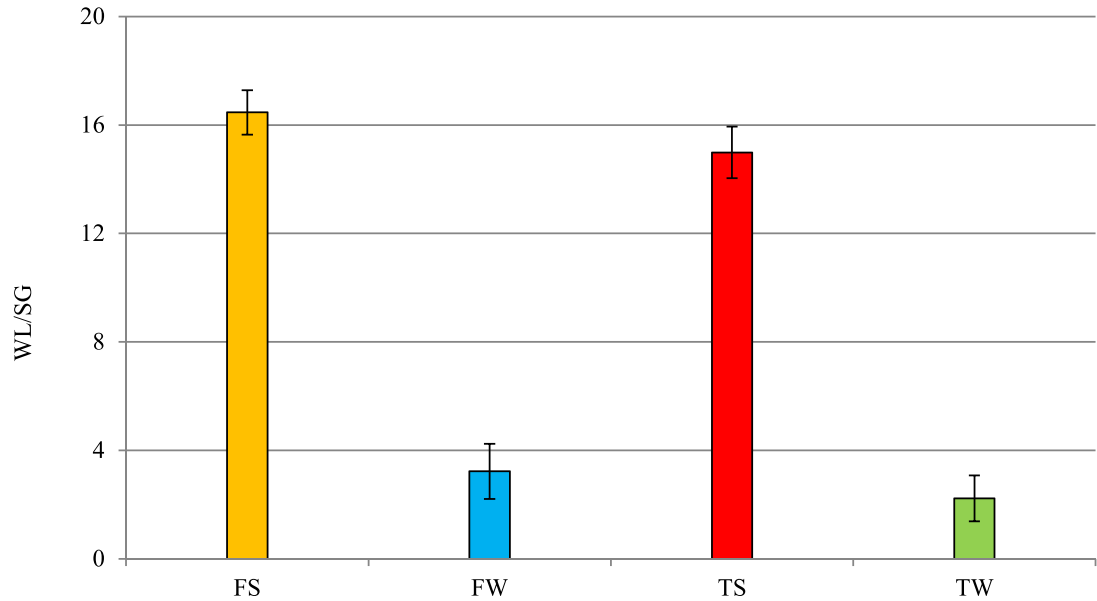

Type of samples 
Fig. 4 Decrease of moisture ratio $(M R)$ versus time of convective drying for untreated and osmotically pretreated frozen sour cherries with stones $(F S)$ and frozen sour cherries without stones $(F W)$

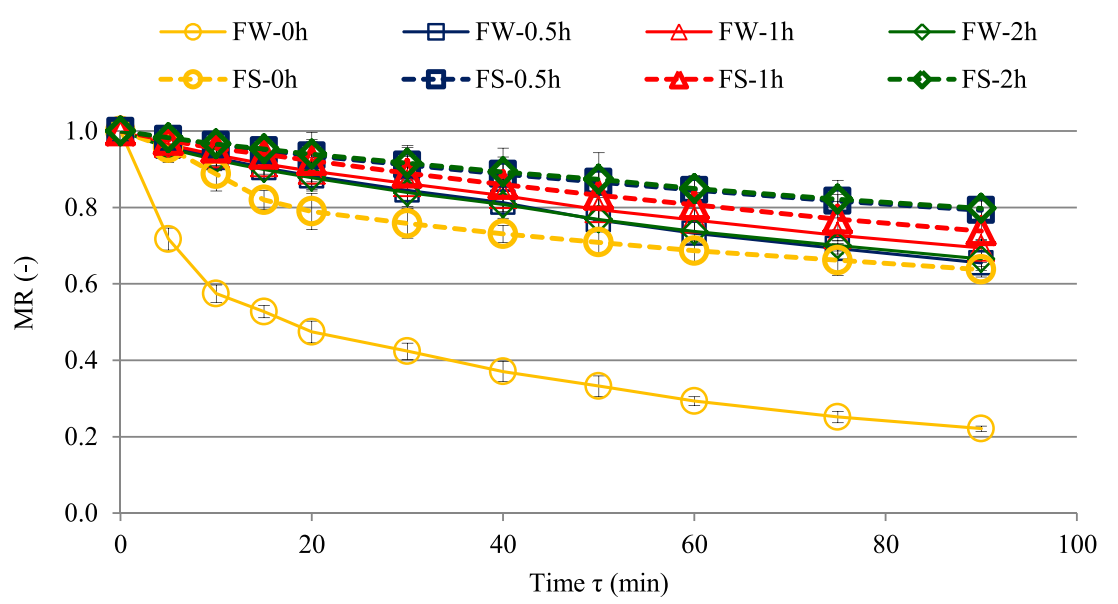

respectively. Stone removal increased VMFD time to $24 \mathrm{~min}$. Namely, the maximal temperature determined for fruits with stones was generally higher than for fruits without stones. This was due to the higher inner pressure resulting from the volume of heated material increasing upon microwave treatment. When the stone was not removed, the unbroken structure of the fruit facilitated generation of a higher inner pressure than in the fruits without stones. Exceptionally, fruits without stones pretreated in the osmotic solution for $2 \mathrm{~h}$ achieved the highest maximal temperature, and therefore, they required only 18 min of VMFD to obtain the same final moisture content as the other samples. In this case, the extremely high temperature might result from the effective impregnation of the fruit structure by the solids clogging the pores, which as unobstructed enabled reduction of the inner pressure. The maximal temperature of all samples measured with infrared camera was increasing in the course of drying time until the certain moisture content and then was decreasing. The similar temperature evolution of dried material with time was observed for beetroot cubes dehydrated by VM drying (Figiel

Table 1 Parameters of Eq. 5 describing the drying kinetics as well as drying time and moisture content of sour cherries dehydrated by osmotic drying $(O D)$, convective drying $(C D)$, and combination of $\mathrm{OD}, \mathrm{CD}$, and vacuum-microwave drying $(V M D)$

\begin{tabular}{|c|c|c|c|c|c|c|c|c|c|c|}
\hline \multirow[t]{2}{*}{ Drying conditions } & \multicolumn{3}{|c|}{ Parameters } & \multicolumn{2}{|c|}{ Statistics } & \multicolumn{3}{|c|}{ Drying time (min) } & \multirow{2}{*}{$\begin{array}{l}M_{O D} \\
\left(\mathrm{~kg} \mathrm{~kg}^{-1} \mathrm{db}\right)\end{array}$} & \multirow{2}{*}{$\begin{array}{l}M_{f} \\
\left(\mathrm{~kg} \mathrm{~kg}^{-1} \mathrm{db}\right.\end{array}$} \\
\hline & $A$ & $k$ & $B$ & RMSE & $R^{2}$ & OD & $\mathrm{CD}$ & VMD & & \\
\hline OD FS & - & - & - & - & - & 180 & - & - & 2.900 & 2.900 \\
\hline OD FW & - & - & - & - & - & 180 & - & - & 2.771 & 2.771 \\
\hline OD TS & - & - & - & - & - & 180 & - & - & 3.242 & 3.242 \\
\hline OD TW & - & - & - & - & - & 180 & - & - & 2.416 & 2.416 \\
\hline CD FW $0 \mathrm{~h}$ & 0.676 & 0.0657 & 0.277 & 0.0466 & 0.9529 & - & 90 & - & - & 2.504 \\
\hline CD FS $0 \mathrm{~h}$ & 0.357 & 0.0400 & 0.645 & 0.0154 & 0.9810 & - & 90 & - & - & 3.511 \\
\hline CD FW $0.5 \mathrm{~h}$ & 0.542 & 0.0106 & 0.448 & 0.0062 & 0.9966 & 30 & 90 & - & 3.916 & 2.564 \\
\hline CD FS $0.5 \mathrm{~h}$ & 0.374 & 0.0087 & 0.622 & 0.0019 & 0.9991 & 30 & 90 & - & 3.595 & 2.851 \\
\hline CD FW $1 \mathrm{~h}$ & 0.480 & 0.0106 & 0.512 & 0.0051 & 0.9970 & 60 & 90 & - & 3.410 & 2.366 \\
\hline CD FS $1 \mathrm{~h}$ & 0.503 & 0.0080 & 0.493 & 0.0020 & 0.9994 & 60 & 90 & - & 3.202 & 2.365 \\
\hline CD FW 2 h & 0.458 & 0.0133 & 0.530 & 0.0064 & 0.9960 & 120 & 90 & - & 2.771 & 1.842 \\
\hline CD FS $2 \mathrm{~h}$ & 0.412 & 0.0074 & 0.586 & 0.0019 & 0.9991 & 120 & 90 & - & 2.900 & 2.313 \\
\hline VMD FW $0 \mathrm{~h}$ & 0.204 & 0.158 & 0 & 0.0048 & 0.9944 & - & 90 & 24 & - & 0.033 \\
\hline VMD FS $0 \mathrm{~h}$ & 0.605 & 0.190 & 0 & 0.0095 & 0.9975 & - & 90 & 21 & - & 0.055 \\
\hline VMD FW $0.5 \mathrm{~h}$ & 0.647 & 0.123 & 0 & 0.0139 & 0.9946 & 30 & 90 & 24 & 3.916 & 0.063 \\
\hline VMD FS $0.5 \mathrm{~h}$ & 0.771 & 0.207 & 0 & 0.0051 & 0.9996 & 30 & 90 & 21 & 3.595 & 0.053 \\
\hline VMD FW $1 \mathrm{~h}$ & 0.663 & 0.175 & 0 & 0.0061 & 0.9991 & 60 & 90 & 21 & 3.410 & 0.034 \\
\hline VMD FS $1 \mathrm{~h}$ & 0.706 & 0.193 & 0 & 0.0057 & 0.9994 & 60 & 90 & 18 & 3.202 & 0.065 \\
\hline VMD FW 2 h & 0.631 & 0.167 & 0 & 0.0150 & 0.9942 & 120 & 90 & 18 & 2.771 & 0.034 \\
\hline VMD FS $2 \mathrm{~h}$ & 0.758 & 0.207 & 0 & 0.0142 & 0.9966 & 120 & 90 & 18 & 2.900 & 0.049 \\
\hline
\end{tabular}

$M_{O D}$ moisture content after $\mathrm{OD}, M_{f}$ final moisture content 
Fig. 5 VM finish drying kinetics of frozen sour cherries with stones (FS), which were previously predried for $90 \mathrm{~min}$ by $\mathrm{CD}$ after osmotic pretreatment for $0,0.5,1$, and $2 \mathrm{~h}$

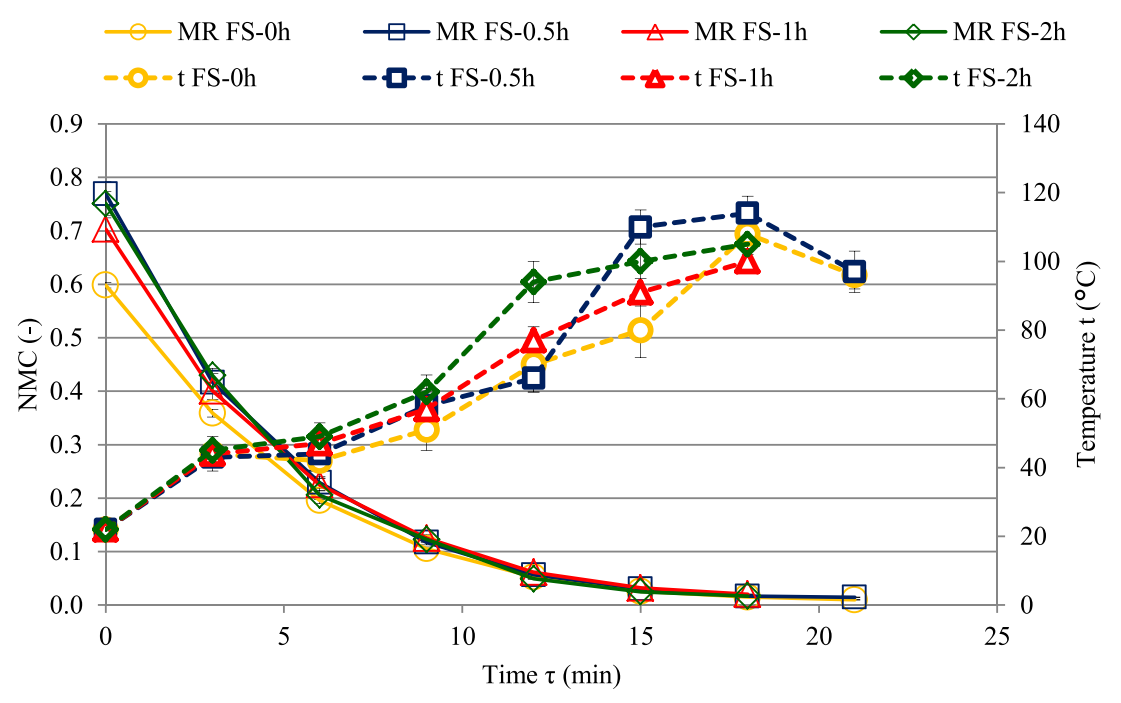

2010). The presence of peak temperature was explained by the coexistence of two phenomena. The first one is the generation of heat energy by water dipoles in the microwave field, while the other one is the absorption of that energy by water evaporating from the surface of the material. Noteworthy is also that the higher values of drying constant $k$ (Table 1 ) determined for the fruits with stones confirmed the remarks above concerning higher inner pressure generated under microwave radiation. Additionally, the study revealed that increasing OD time from zero to $0.5 \mathrm{~h}$ for fruits with stones and to $1 \mathrm{~h}$ for fruits without stones increased the values of $k$ from initial 0.19 and $0.158 \mathrm{~min}^{-1}$ to maximal 0.207 and $0.175 \mathrm{~min}^{-1}$, respectively. Further increasing of OD time did not contribute to the increasing of $k$ values in both cases. The optimal OD time in terms of VM finish drying kinetics requires more consideration. Namely, increasing OD time from 0 to $0.5 \mathrm{~h}$ for fruits with stones and to $1 \mathrm{~h}$ for fruits without stones increased the peak temperature of the samples from 105 and $100{ }^{\circ} \mathrm{C}$ to 114 and $103{ }^{\circ} \mathrm{C}$, respectively, which promotes the generation of high inner pressure enabling fast removal of water through optimally impregnated peal of fruit with stone and the external layer of fruits without stone. Further increasing of OD time causing decreasing of peak temperature recorded for fruits with stone, which indicates that the inner pressure was also decreasing probably due to alterations occurring inside the impregnated peal. In the case of fruits without stone, the peak temperature increased to $117^{\circ} \mathrm{C}$ but did not contribute to $k$ value increase. This may be due to the fact that the capillaries within the material were extensively filled with the solids from the apple concentrate, making the transport of water to the surface of the material too difficult. Excessive enrichment of this surface with solids from the concentrate could additionally hinder the evaporation of water. Similar findings were obtained during VM finish drying of strawberries and apples pretreated in a sucrose solution (Erle and Schubert 2001).

The time saving resulting from the application of VMFD can be derived from Fig. 7 which depicts examples of combined drying kinetics for frozen sour cherries without stones
Fig. 6 VM finish drying kinetics of frozen sour cherries without stones $(F W)$, which were previously predried for $90 \mathrm{~min}$ by $\mathrm{CD}$ after osmotic pretreatment for $0,0.5,1$, and $2 \mathrm{~h}$

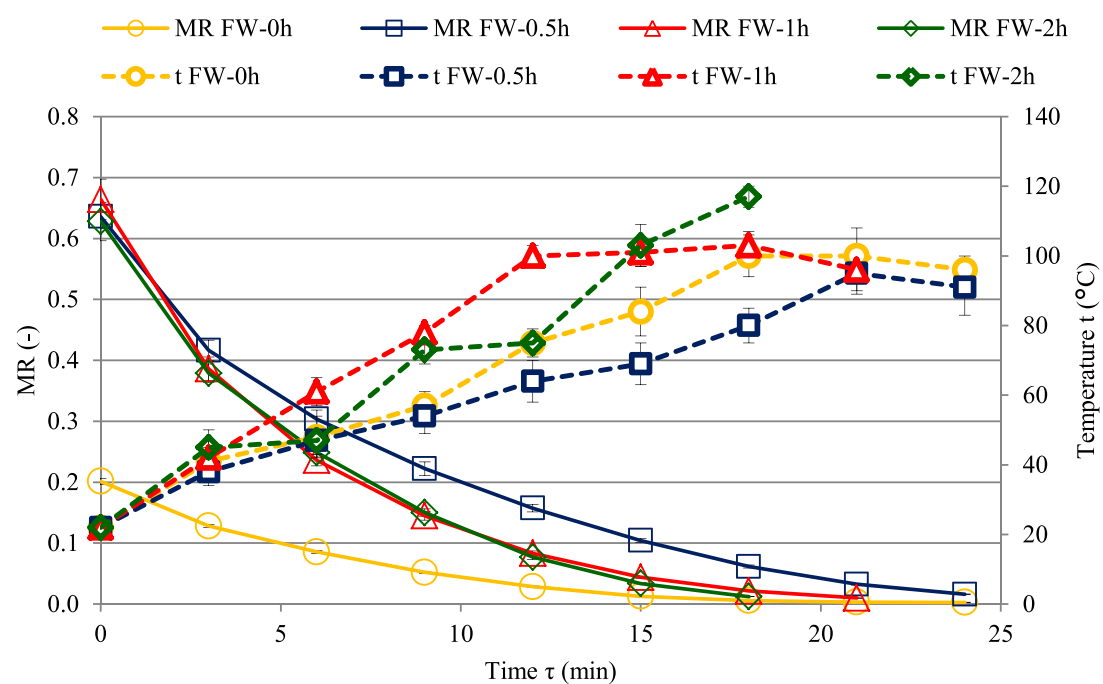


Fig. 7 Examples of combined drying kinetics for frozen sour cherries without stones consisting of convective predrying for 90 min and VM finish drying (a) as well as osmotic pretreatment for $2 \mathrm{~h}$, convective meantime drying for $90 \mathrm{~min}$ and VM finish drying (b). Abbreviations in parentheses refer to the history of dehydration prior to particular type of drying

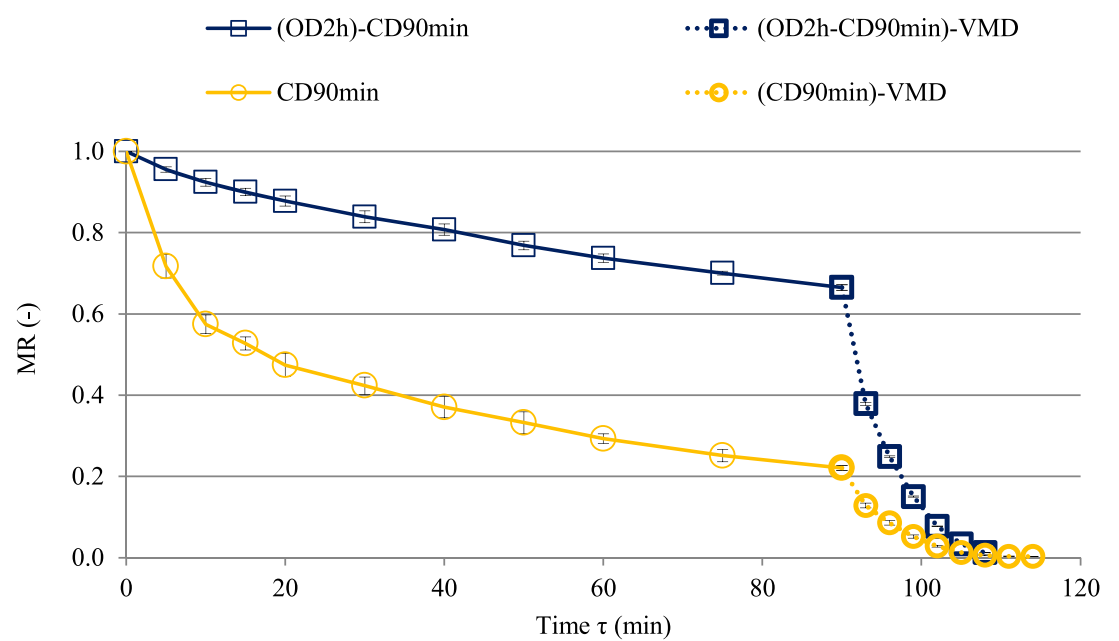

consisting of convective predrying for $90 \mathrm{~min}$ and $\mathrm{VM}$ finish drying as well as $\mathrm{CD}$ for $90 \mathrm{~min}$ and VM finish drying applied after osmotic pretreatment for $2 \mathrm{~h}$. While the value of drying constant $k$ for convective dehydration amounted to $0.0657 \mathrm{~min}^{-1}$, the introduction of VMFD significantly increased this value to about $0.14 \mathrm{~min}^{-1}$ and thus considerably reduced the duration of the entire dewatering process (Table 1). The benefits of using VMFD concern not only the time of drying and energy consumption (Calín-Sanchez et al. 2014), but also the quality of dried product in terms of sensory attributes and chemical composition (Calín-Sanchez et al. 2014) as well as their potential bioactivity (Wojdyło et al. 2014).

\section{Polyphenolics Content and Antioxidant Activity During Osmotic Dehydration Method}

An important issue during the dehydration process of fruits is preservation of their nutritional value, especially the protection of polyphenolic compounds that directly affect the antioxidant activity and sensory characteristics of the final product (Sumic et al. 2013).

The initial value of total polyphenols (TP) in the fresh samples was $1470.51 \mathrm{mg} \mathrm{GA} / 100 \mathrm{~g} \mathrm{dm}$. This result is similar to those described by Sumic et al. (2013) - 1368 CAE mg/ $100 \mathrm{~g} \mathrm{dm}$ and also by Serra et al. (2011); however, they suggested that the content of TP was depending on the variety of sour cherries. Lower values were reported for the materials used for the OD, because they were earlier frozen. Thus, the content of total phenolics in untreated samples was successively: $1220.50,1086.27,1288.46$, and $1157.21 \mathrm{mg} \mathrm{GA} /$ $100 \mathrm{~g} \mathrm{dm}$ for FW, TW, FS, and TS, respectively. The lower content of these compounds in TW and TS was due to the fact that before freezing process, they were stoned or due to losses of phytochemical compounds during defrosting process.

OD had a significant influence on components compared to the untreated samples (Table 2). Especially during the first
60 min of the OD process (at 30 and $60 \mathrm{~min}$ ), a significant drop can be seen in the content of polyphenols. It is connected with an intensive exchange of mass during the first phase of OD (Tylewicz et al. 2011) associated with migration of phenolic compounds from dehydrated sour cherry fruits to apple concentrate and mainly with migration of solids of a low bioactive potential from the concentrate to the fruits induced by a large osmotic driving force. This fact was due to the greater difference in the concentration between fruits and the surrounding hypertonic medium (Bchir et al. 2012a, b, c). This was confirmed by a jump of $S G$ value (Fig. 2), which was particularly high in the case of TW and FW fruits amounting to 11.65 and $10.13 \mathrm{~g} / 100 \mathrm{~g}$ of fresh fruits, respectively. Additionally, these types of dehydrated fruits were characterized by relatively low $W L / S G$ ratio amounting to 2.23 and 3.22 (Fig. 3), which negatively affects the quality of OD product (Sereno et al. 2001). In the second hour of OD process, a slight increase of the polyphenol content or its stabilization might be observed, which was most likely caused by changes in the structure of the raw material due to OD and reduced driving force (Rząca et al. 2009). This is again followed by degradation of these compounds, which is due to the fact that OD time significantly affects the properties of cell membranes. Over time, they lose their capability for selective transport, and much more osmotic substance gets into the cells (Piasecka et al. 2009), which was particularly seen in the case of FW fruits, when the value of SG increased from 4.93 to $10.13 \mathrm{~g} / 100 \mathrm{~g}$ of fresh fruits in the last hour of OD.

The greatest degradation of polyphenolic compounds during OD was shown for TW, the loss of phenolics was at $47.40 \%$, while the smallest loss of polyphenols was in FS and TS, i.e., 16.92 and $19.52 \%$, respectively. Uczciwek et al. (2011) noted a $17 \%$ decrease of polyphenols in TW sour cherries, but the OD process applied in their study lasted only $60 \mathrm{~min}$ and was conducted in a fructooligosaccharide concentrate with $60^{\circ}$ Brix. The high loss of polyphenolic compounds 
Table 2 Effect of osmotic dehydration time (OD time) of different kind of sour cherries (FS, FW, TS, TW) on polyphenol content [mg GA/ $100 \mathrm{~g} \mathrm{dm}$ ] and antioxidant activity [mmol TE/100 $\mathrm{g} \mathrm{dm}$ ]

\begin{tabular}{|c|c|c|c|}
\hline $\begin{array}{l}\text { Kind of sour } \\
\text { cherry }\end{array}$ & $\begin{array}{l}\text { OD time } \\
{[\mathrm{min}]}\end{array}$ & Polyphenol content & ABTS \\
\hline \multirow[t]{6}{*}{ Fresh FS ${ }^{\mathrm{a}}$} & - & $1470.51 \pm 5.12 \mathrm{a}^{\#}$ & $20.66 \pm 1.07 \mathrm{a}$ \\
\hline & 0 & $1288.46 \pm 27.95 b$ & $10.22 \pm 0.20 \mathrm{~b}$ \\
\hline & 30 & $1062.61 \pm 36.15 \mathrm{~h}$ & $7.31 \pm 0.32 \mathrm{e}-\mathrm{i}$ \\
\hline & 60 & $1129.37 \pm 16.17 \mathrm{ef}$ & $8.39 \pm 0.99 \mathrm{c}-\mathrm{e}$ \\
\hline & 120 & $1177.81 \pm 13.85 \mathrm{~d}$ & $8.25 \pm 0.07 \mathrm{c}-\mathrm{f}$ \\
\hline & 180 & $1070.49 \pm 10.71 \mathrm{~h}$ & $7.79 \pm 0.35 \mathrm{~d}-\mathrm{h}$ \\
\hline \multirow[t]{5}{*}{$\mathrm{FW}^{\mathrm{b}}$} & 0 & $1220.50 \pm 3.13 c$ & $10.30 \pm 0.58 b$ \\
\hline & 30 & $1114.28 \pm 1.12 \mathrm{fg}$ & $9.78 \pm 0.14 b$ \\
\hline & 60 & $968.99 \pm 28.04 \mathrm{i}$ & $7.76 \pm 0.68 \mathrm{~d}-\mathrm{i}$ \\
\hline & 120 & $948.40 \pm 22.47 \mathrm{ij}$ & $8.09 \pm 0.70 \mathrm{~d}-\mathrm{g}$ \\
\hline & 180 & $820.56 \pm 4.321$ & $6.96 \pm 0.08 \mathrm{~g}-\mathrm{i}$ \\
\hline \multirow[t]{5}{*}{$\mathrm{TS}^{\mathrm{c}}$} & 0 & $1157.21 \pm 36.05 \mathrm{de}$ & $8.59 \pm 0.06 \mathrm{~cd}$ \\
\hline & 30 & $1078.89 \pm 10.62 \mathrm{gh}$ & $7.05 \pm 0.45 \mathrm{fg}-\mathrm{i}$ \\
\hline & 60 & $1070.23 \pm 15.71 \mathrm{~h}$ & $7.41 \pm 0.21 \mathrm{~d}-\mathrm{i}$ \\
\hline & 120 & $1108.83 \pm 16.78 \mathrm{fg}$ & $6.56 \pm 1.11 \mathrm{i}$ \\
\hline & 180 & $931.37 \pm 3.72 j$ & $6.21 \pm 0.18 \mathrm{hi}$ \\
\hline \multirow[t]{5}{*}{$\mathrm{TW}^{\mathrm{d}}$} & 0 & $1086.27 \pm 9.88 \mathrm{gh}$ & $9.91 \pm 0.01 \mathrm{~b}$ \\
\hline & 30 & $1106.37 \pm 13.23 \mathrm{fg}$ & $9.35 \pm 0.32 b c$ \\
\hline & 60 & $862.59 \pm 13.80 \mathrm{k}$ & $8.45 \pm 1.99 \mathrm{c}-\mathrm{e}$ \\
\hline & 120 & $932.49 \pm 6.30 \mathrm{j}$ & $7.97 \pm 0.04 \mathrm{~d}-\mathrm{g}$ \\
\hline & 180 & $514.89 \pm 6.30 \mathrm{~m}$ & $4.72 \pm 0.17 \mathrm{j}$ \\
\hline
\end{tabular}

\# Values followed by the same letter, within the same column, were not significantly different $(p<0.05)$, according to Duncan's test

${ }^{\mathrm{a}}$ Frozen with stone

${ }^{\mathrm{b}}$ Frozen without stone

${ }^{\mathrm{c}}$ Thawed with stone

${ }^{\mathrm{d}}$ Thawed without stone

in TW sour cherries was probably caused by damage to the structure of the tissue during freezing (Białas et al. 2004) and facilitated juice leakage due to damage to the fruit skin during pitting. Therefore, the highest content of polyphenols after the OD process was determined in FS sour cherries - $1070.49 \mathrm{mg}$ $\mathrm{GA} / 100 \mathrm{~g} \mathrm{dm}$. For this type of sample, the $S G$ value was merely $1.50 \mathrm{~g} / 100 \mathrm{~g}$ of fresh fruits (Fig. 2) at a very high value of $W L / S G$ ratio amounting to 16.47 (Fig. 3).

Analysis of the antioxidant activity showed that it was positively correlated with the polyphenol content (Table 2). This correlation was also confirmed in our previous work (Wojdyło et al. 2014).

The highest antioxidant activity measured by ABTS after $3 \mathrm{~h}$ of OD process was reported for FS sour cherries$7.79 \mathrm{mmol} \mathrm{TE} / 100 \mathrm{~g} \mathrm{dm}$. The lowest antioxidant activity in FS was recorded after $30 \mathrm{~min}$ and $180 \mathrm{~min}$ OD-7.31 and $7.79 \mathrm{mmol} \mathrm{TE} / 100 \mathrm{~g} \mathrm{dm}$, and for FW after $60 \mathrm{~min}$ and $180 \mathrm{~min}$ OD -7.76 and $6.96 \mathrm{mmol} \mathrm{TE} / 100 \mathrm{~g} \mathrm{dm}$. These values were significantly different $(p<0.05)$ from the lowest antioxidant activity determined for TS (after $120 \mathrm{~min}$ OD $6.56 \mathrm{mmol}$ TE/100 g dm) and TW (after $180 \mathrm{~min}$ OD-4.72 mmol TE/ $100 \mathrm{~g} \mathrm{dm}$ ). The low results of the antioxidant activity in the initial phase of the OD may be due to, as in the case of the content of polyphenols, intensive migration of phenolic compounds from pulp to the surrounding medium (Bchir et al. 2012c; Tylewicz et al. 2011). In contrast, the low value of the antioxidant activity after $120 \mathrm{~min}$ of OD process results from changes in the permeability of cell membranes, and also probably from long exposure of the product to high temperature, which causes the destruction of some phenolic compounds, and thus the loss of antioxidant activity (Wojdyło et al. 2007). Therefore, it seems most reasonable to conduct the OD process in apple concentrate for $2 \mathrm{~h}$, assuming the same initial parameters.

Both in the case of FS, FW, and TS sour cherries, it can be seen that with the increase of dry matter during the OD process, the antioxidant activity decreases. This may be due to the increase in dry matter connected with water loss and increase of carbohydrates in the OD material (Torres et al. 2007). With the loss of water, also components dissolved in water are discharged to the surrounding medium, including the hydrophilic substances which affect the antioxidant activity of the final products.

It is difficult to determine whether OD in apple concentrate influences better the content of polyphenolic compounds and antioxidant capacity in the final products, as in sucrose solution, because the OD process of sour cherries has never been carried out in such medium before. Therefore, the mechanism of antioxidant activity changes during the OD in apple concentrate of sour cherries needs more consideration.

\section{Polyphenolics Content and Antioxidant Activity During Combined Drying Method (OD-CD-VMD)}

Table 3 demonstrates the content of total polyphenols and antioxidant activity determined by ABTS method of frozen sour cherries, with and without stones, which were previously predried for $90 \mathrm{~min}$ by $\mathrm{CD}$ after osmotic pretreatment for 0 , 30, 60, and $120 \mathrm{~min}$ and after that VM dried. Data in Table 3 indicate changes in polyphenol content and antioxidant activity in OD medium. The obtained results show that the combination of the CD and VMD is a very effective method of food preservation, including its high nutritional value. The content of polyphenols in the analyzed fruits decreased insignificantly compared with the initial material. Similar results were obtained by Wojdyło et al. (2014), who used the VM drying at different wattage of microwaves. They also recorded slight degradation of polyphenols of sour cherries. The advisability of using predrying of the material by convective method before VMFD was also confirmed by Durance and Wang 
Table 3 Effect of osmotic dehydration time of FS and FW sour cherries on polyphenol content $[\mathrm{mg} \mathrm{GA} / 100 \mathrm{~g} \mathrm{dm}$ ] and antioxidant activity [mmol $\mathrm{TE} / 100 \mathrm{~g} \mathrm{dm}$ ] in OD-CD-VMD dry sour cherries and their osmotic medium [apple concentrate; $40^{\circ}$ Brix; $45^{\circ} \mathrm{C}$ ]

\begin{tabular}{|c|c|c|c|c|}
\hline \multirow{2}{*}{$\begin{array}{l}\text { OD } \\
\text { time } \\
{[\mathrm{min}]}\end{array}$} & \multicolumn{2}{|l|}{ Polyphenol content } & \multicolumn{2}{|l|}{ ABTS } \\
\hline & $\mathrm{FS}^{\mathrm{a}}$ & Medium's OD & FS & $\begin{array}{l}\text { Medium's } \\
\text { OD }\end{array}$ \\
\hline 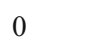 & $1462.00 \pm 59.26 \mathrm{a}^{\#}$ & $117.36 \pm 9.03 \mathrm{c}$ & $11.47 \pm 0.17 \mathrm{a}$ & $0.67 \pm 0.10 \mathrm{~b}$ \\
\hline 30 & $1484.72 \pm 43.08 \mathrm{a}$ & $151.14 \pm 5.02 \mathrm{a}$ & $10.84 \pm 0.37 \mathrm{ab}$ & $0.91 \pm 0.08 \mathrm{a}$ \\
\hline 60 & $1214.15 \pm 17.22 \mathrm{c}$ & $145.38 \pm 2.96 \mathrm{ab}$ & $9.39 \pm 0.11 \mathrm{c}$ & $0.91 \pm 0.13 \mathrm{a}$ \\
\hline 120 & $\begin{array}{l}1223.51 \pm 39.75 \mathrm{c} \\
\mathrm{FW}^{\mathrm{b}}\end{array}$ & $136.58 \pm 2.34 \mathrm{~b}$ & $\begin{array}{l}9.96 \pm 0.50 \mathrm{bc} \\
\mathrm{FW}\end{array}$ & $0.91 \pm 0.04 \mathrm{a}$ \\
\hline 0 & $1357.44 \pm 55.79 b$ & $117.36 \pm 9.03 \mathrm{c}$ & $11.15 \pm 0.16 \mathrm{a}$ & $0.67 \pm 0.10 \mathrm{~b}$ \\
\hline 30 & $1153.02 \pm 41.53 \mathrm{c}$ & $140.71 \pm 2.45 \mathrm{ab}$ & $9.57 \pm 0.08 \mathrm{c}$ & $0.95 \pm 0.04 \mathrm{a}$ \\
\hline 60 & $1180.40 \pm 9.79 \mathrm{c}$ & $134.40 \pm 7.24 \mathrm{~b}$ & $9.41 \pm 0.17 \mathrm{c}$ & $0.83 \pm 0.06 a$ \\
\hline 120 & $1195.51 \pm 17.59 \mathrm{c}$ & $138.84 \pm 2.40 \mathrm{~b}$ & $8.02 \pm 1.31 \mathrm{~d}$ & $0.88 \pm 0.02 \mathrm{a}$ \\
\hline
\end{tabular}

\# Values followed by the same letter, within the same column, were not significantly different $(p<0.05)$, according to Duncan's test

${ }^{\text {a }}$ Frozen with stone

${ }^{\mathrm{b}}$ Frozen without stone

(2002), who obtained lower costs of dehydration and a high nutritional value of tomatoes and strawberries.

The use of OD process before CD-VMD resulted in a slight degradation of polyphenolic compounds. Wherein, depending on the type of raw material, the greatest decrease in the polyphenol content was recorded after different time - in the case $\mathrm{FW}$ in the first $30 \mathrm{~min}$ of OD process (polyphenol degradation of $16.4 \%$ ), in the case of FS after $60 \mathrm{~min}$ of dehydration (decrease in polyphenol content of $16.96 \%$ ). It was directly correlated with the values of the antioxidant activity which in FS ranged from 9.39 (after 60 min the OD process) to 10.84 (after $30 \mathrm{~min}$ ), and during the OD of FW from 8.02 (after $120 \mathrm{~min}$ of OD) to $9.57 \mathrm{mmol} \mathrm{TE} / 100 \mathrm{~g} \mathrm{dm}$ (after $30 \mathrm{~min}$ of OD). Taking into account that polyphenol content and antioxidant activity of processed sour cherries were affected mainly by OD process, it was hard to find the direct impact of peak temperature on the bioactive potential of VMFD samples, in contrast to the results obtained in the previous studies performed by Wojdyło et al. (2014). The changes occurring during the OD can also be seen in the OD medium. The process of mass exchange between apple juice and sour cherry fruit caused the transfer of polyphenolic compounds to apple juice, and thus increased its antioxidant activity. The highest antioxidant activity determined by ABTS method was obtained in apple juice after 30-min OD$0.95 \mathrm{mmol} \mathrm{TE} / 100 \mathrm{ml}$, which is by $41.8 \%$ higher than the antioxidant activity of untreated juice $(0.67 \mathrm{mmol} \mathrm{TE} / 100 \mathrm{ml})$.

The obtained results show that the attempt to apply apple juice as an OD's medium, during combined OD-CD-VMD method, does not contribute to the increase in the content of polyphenolic compounds and antioxidant activity of the final product. Likely, this is due to the characteristics of untreated medium, i.e., relatively low antioxidant activity and total polyphenol content. Therefore, attempts are considered to use at this stage other types of media that during the OD could affect the increase of nutrients in dehydrated material. However, OD is an important step in the production of dehydrated dry material, because it leads to moisture content decrease by more than $50 \%$. For this reason, the successive stages, i.e., $\mathrm{CD}$ and VMD drying, may be conducted in a shorter period of time, at lower temperature and lower wattage of microwaves.

\section{Conclusions}

The study revealed that the decrease of $W L / S G$ ratio during OD of frozen sour cherries in apple concentrate associated with increased water loss $(W L)$ and solid gain $(S G)$ can be considerably enhanced by removing the stone. The process of thawing prior to OD additionally contributed to the lowering of $W L / S G$ ratio. It was found that logarithmic model enabled overall description of drying kinetics of combined drying consisting of $\mathrm{CD}$ and VMFD performed after OD. The increase in OD time resulted in a decreasing drying constant for $\mathrm{CD}$. On the other hand, the highest value of this parameter for VMFD was achieved after optimal time of OD reaching 0.5 and $1 \mathrm{~h}$ for FS and FW fruits, respectively. The optimal time of OD in terms of drying kinetics was associated with achieving a peak temperature of VMFD material. However, the direct impact of the peak temperature on the bioactive potential of VMFD samples was not stated. The best variant of sour cherry, to be used for OD in apple concentrate, was frozen cherry with stone (FS). It is characterized by the high content of polyphenols, antioxidant activity, and the lowest $S G$ at the largest $W L / S G$ ratio during OD process. Considering the quality factors of the final products, namely, the polyphenol content and antioxidant activity, OD time in apple medium should be $120 \mathrm{~min}$, in the same operating conditions: $120-\mathrm{mL}$ diluted apple concentrate to $40^{\circ} \mathrm{Brix}$, process temperature $-40^{\circ} \mathrm{C}$ and weight of OD samples $-60 \mathrm{~g}$. These parameters ensure dehydration of sour cherry by more than $50 \%$ and preservation of its nutritional value. The drying process of osmotically dehydrated cherry fruits may be conducted within 90 min using predrying by $\mathrm{CD}\left(50{ }^{\circ} \mathrm{C}, 0.8 \mathrm{~m} / \mathrm{s}\right)$ and finish drying by VMD (4-6 kPa, $360 \mathrm{~W})$, because it allows not only reducing costs of dehydration but also ensuring a high nutritional value of sour cherries.

Acknowledgments This work was supported by the NCN Poland, project no. UMO-2011/01/B/NZ9/07139. The authors would like to thank Piotr Laskowski from Research Station for Cultivar Testing in Zybiszów near Wroclaw for providing the fruit materials. 
Open Access This article is distributed under the terms of the Creative Commons Attribution License which permits any use, distribution, and reproduction in any medium, provided the original author(s) and the source are credited.

\section{References}

Abraao, A. S., Lemons, A. M., Vilela, A., Sousa, J. M., \& Nunes, F. M. (2013). Influence of osmotic dehydration process parameters on the quality of candied pumpkins. Food and Bioproducts Processing, 91, 481-494.

Aghbashlo, M., Kianmehr, M. H., \& Hassa-Beygi, S. R. (2010). Drying and rehydration characteristics of sour cherry (Prunus cerasus L.). Journal of Food Processing and Preservation, 34, 351-365.

Alibas, I. (2006). Characteristics of chard leaves during microwave, convective, and combined microwave-convective drying. Drying Technology, 24(11), 1425-1435.

Azoubel, P. M., \& Murr, F. E. X. (2003). Optimisation of osmotic dehydration of cashew apple (Anacardium Occidentale L.) in sugar solutions. Food Science and Technology International, 9(6), 427-433.

Bchir, B., Besbes, S., Attia, H., \& Blecker, C. (2012a). Osmotic dehydration of pomegranate seeds (Punica granatum L.): effect of freezing pre-treatment. Journal of Food Process Engineering, 35, 335-354.

Bchir, B., Besbes, S., Karoui, R., Attia, H., Paquot, M., \& Blecker, C. (2012b). Effect of air-drying conditions on physic-chemical properties of osmotically pre-treated pomegranate seeds. Food and Bioprocess Technology, 5, 1840-1852.

Bchir, B., Besbes, S., Karoui, R., Paquot, M., Attia, H., \& Blecker, C. (2012c). Osmotic dehydration kinetics of pomegranate seeds using date juice as an immersion solution base. Food and Bioprocess Technology, 5, 999-1009.

Białas, W., Modzelewska, A., Grajek, W., \& Jankowski, T. (2004). The effect of maltodextrine coating on losses in weight and firmness of strawberries being thawed. ŻYWNOŚĆ. Nauka. Technologia. Jakość, 4(41), 41-51.

Bohm, V., Kuhnert, S., Rohm, H., \& Scholze, G. (2006). Improving the nutritional quality of microwave-vacuum dried strawberries: a preliminary study. Food Science and Technology International, 12, 6775.

Calín-Sanchez, A., Figiel, A., Szarycz, M., Lech, K., Nuncio-Jáuregui, N., \& Carbonell-Barrachina, Á. A. (2014). Drying kinetics and energy consumption in the dehydration of pomegranate (Punica granatum L.) arils and rind. Food and Bioprocess Technology, 7, 2071-2083.

Durance, T. D., \& Wang, J. H. (2002). Energy consumption, density, and rehydration rate of vacuum-microwave and hotair convection-dehydrated tomatoes. Journal of Food Science, 67(6), 2212-2216.

El-Aouar, A., Azoubel, P., \& Murr, F. (2003). Drying kinetics of fresh and osmotically pre-treated papaya (Carica papaya L.). Journal of Food Engineering, 59, 85-91.

Erle, U., \& Schubert, H. (2001). Combined osmotic and microwavevacuum dehydration of apples and strawberries. Journal of Food Engineering, 49(2-3), 193-199.

Falade, K. O., \& Adelakun, A. T. (2007). Effect of prefreezing and solutes on mass transfer during osmotic dehydration and colour of ovendried African star apple during storage. International Journal of Food Science and Technology, 42, 394-402.

Figiel, A. (2010). Drying kinetics and quality of beetroots dehydrated by combination of convective and vacuum-microwave methods. Journal of Food Engineering, 98, 461-470.

Figiel, A., Nawirska, A., Wojdyło, A., Korzeniowska, M., Oziembłowski, M., Biesiada, A. (2011). Some quality factors of freeze-dried pumpkin slices as affected by osmotic pre-treatment in chokeberry juice. Book of Abstracts. Agrophysics for Quality of Life, 61-62.

Gao, X., Ohlander, M., Jeppsson, N., Bjork, L., \& Trajkovski, V. (2000). Changes in antioxidant effects and their relationship to phytonutrients in fruits of sea buckthorn (Hippophae rhamnoides L.) during maturation. Journal of Agricultural and Food Chemistry, 48(5), 1485-1490.

Gomez, F. G., \& Sjoholm, I. (2004). Applying biochemical and physiological principles in the industrial freezing of vegetables: a case study on carrots. Trends in Food Science \& Technology, 15, 39-43.

Halvorsen, B. L., Holte, K., Myhrstad, M. C. W., Barikmo, I., Hvattum, E., Remberg, S. F., Wold, A. B., Haffner, K., Baugerod, H., \& Andersen, L. F. (2002). A systematic screening of total antioxidants in dietary plants. Journal Nutrition, 132, 461-471.

Kowalska, H., Lenart, A., \& Leszczyk, D. (2008). The effect of blanching and freezing on osmotic dehydration of pumpkin. Journal of Food Engineering, 86, 30-38.

Lazarides, H. N., \& Mavroudis, N. E. (1995). Freeze/thaw effects on mass transfer during osmotic dehydration. Journal of Food Science, 60, 826-828.

Lech, K., Figiel, A., Korzeniowska, M., Oziembłowski, M., NawirskaOlszańska, A., Kolniak-Ostek, J. (2012). Effect of the osmotic solution temperature on some quality properties of vacuummicrowave finish dried beetroot slices. 18th International Drying Symposium, Xiamen, China, 11-15 November 2012. Book of Abstracts, 139-140.

Lenart, A. (1992). Mathematical modeling of osmotic dehydration of apple and carrot. Acta Alimentaria Polnica, 1(42), 33-44.

Mandala, I., Anagnostaras, E., \& Oikonomou, C. (2005). Influence of osmotic dehydration conditions on apple air-drying kinetics and their quality characteristics. Journal of Food Engineering, 69, 307-316.

Maskan, M. (2000). Microwave/air and microwave finish drying of banana. Journal of Food Engineering, 44, 71-78.

Mayor, L., \& Sereno, A. M. (2004). Modeling shrinkage during convective drying of food materials: a review. Journal of Food Engineering, 61, 373-386.

Nowacka, M., Tylewicz, U., Laghi, L., Dalla, R. M., \& Witrowa-Rajchert, D. (2014). Effect of ultrasound treatment on the water state in kiwifruit during osmotic dehydration. Food Chemistry, 144, 18-25.

Nowicka, P., Wojdyło, A., \& Oszmiański, J. (2013). The Quality of sour cherry commercial product. Przemyst Fermentacyjny $i$ OwocowoWarzywny, 7-8, 40-45 (in polish).

Piasecka, E., Uczciwek, M., \& Klewicki, R. (2009). Osmotic dehydration of fruits in solutions containing fructooligosaccharides. ŻYWNOŚ́. Nauka. Technologia. Jakość, 2(63), 138-153.

Re, R., Pellegrini, N., Proteggente, A., Pannala, A., Yang, M., \& RiceEvans, C. (1999). Antioxidant activity applying an improves ABTS radical cation decolorization assay. Free Radical Biology \& Medicine, 26(9/10), 1231-1237.

Rząca, M., Witrowa-Rajchert, D., Tylewicz, U., \& Dalla, R. M. (2009). Mass exchange in osmotic dehydration process of kiwi fruits. ŻYWNOŚĆ. Nauka. Technologia. Jakość, 6(67), 140-149.

Sereno, A. M., Moreira, R., \& Martinez, E. (2001). Mass transfer coefficients during osmotic dehydration of apple in single and combined aqueous solutions of sugar and salt. Journal of Food Engineering, 47(1), 43-49.

Serra, A. T., Duarte, R. O., Bronze, M. R., \& Duarte, C. M. M. (2011). Identification of bioactive response in traditional cherries from Portugal. Food Chemistry, 125, 318-325.

Seymour, M., Singer, A. A. M., Kirakosyan, A., Urcuyo-Lianes, D. E., Kaufman, P. B., \& Bolling, S. F. (2008). Altered hyperlipidemia, hepatic steatosis, and hepatic peroxisome proliferator-activated receptors in rats with intake of tart cherry. Journal of Medicinal Food, 11(2), 252-259. 
Sumic, Z., Tepic, A., Vidovic, S., Jokic, S., \& Malbasa, R. (2013). Optimization of frozen sour cherries vacuum drying process. Food Chemistry, 136, 55-63.

Tarhan, S., Ergunes, G., \& Taser, O. F. (2006). Selection of chemical and thermal pretreatment combination to reduce the dehydration time of sour cherry (Prunus cerasus L.). Journal of Food Process Engineering, 29, 651-663.

Torres, J. D., Talens, P., Carot, J. M., Chiralt, A., \& Escriche, I. (2007). Volatile profile of mango (Mangifera indica L.), as affected by osmotic dehydration. Food Chemistry, 101, 219-228.

Tylewicz, U., Panarese, V., Laghi, L., Rocculi, P., Nowacka, M., Placucci, G., \& Dalla, R. M. (2011). NMR and DSC water study during osmotic dehydration of Actinidia deliciosa and A. chinensis kiwifruit. Food Biophysics, 6, 327-333.

Uczciwek, M., Piasecka, E., Klewicki, R., Konopacka, D., Mieszczakowska-Frąc, R., \& Bonazzi, C. (2011). Content of selected nutrients in sour cherries, blackcurrants and apples osmodehydrated in reused fructooligosaccharide concentrate. Italian Journal of Food Science, 23, 270-278.

Williams, P. G. (2005). Consumer understanding and use of health claims for foods. Nutrition Reviews, 63(7), 256-264.

Wojdyło, A., Figiel, A., \& Oszmiański, J. (2007). Influence of temperature and time of apple drying on phenolic compounds content and their antioxidant activity. Polish Journal of Food and Nutrition Sciences, 57(4), 601-605.

Wojdyło, A., Figiel, A., \& Oszmiański, J. (2009). Effect of drying methods with application of vacuum microwaves on the bioactive compounds, color, and antioxidant activity of strawberry fruits. Journal of Agricultural and Food Chemistry, 57(4), 1337-1343.

Wojdyło, A., Figiel, A., Lech, K., Nowicka, P., \& Oszmiański, J. (2014). Effect of convective and vacuum-microwave drying on the bioactive compounds, color, and antioxidant capacity of sour cherries. Food Bioprocess Technology, 7, 829-841. 